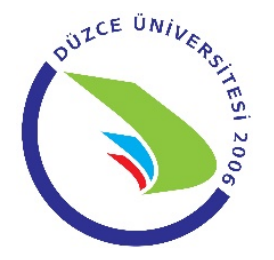

\title{
Evaluation of Clinical and Epidemiological Characteristics of Tularemia Suspected Cases in Kastamonu between 2014-2017 years
}

\author{
Hasan Tahsin GÖZDAŞ ${ }^{1}$, Abdullah Onur GÖKSEL [0] ${ }^{2}$
}

\begin{abstract}
Aim: Tularemia is a zoonosis caused by Francisella tularensis. It appears as local outbreaks or sporadic cases. The aim of this study was to evaluate tularemia suspected cases in terms of clinical and epidemiological characteristics during admission.

Material and Methods: Thirty six tularemia suspected cases were evaluated retrospectively in terms of clinical and epidemiological characteristics between 2014-2017 years. Diagnosis was made when tularemia microagglutination test was positive at $1 / 160$ titer and above.

Results: Among 36 suspected patients, four (11\%) was diagnosed with tularemia. Of the total four cases diagnosed with tularemia, three applied in 2017 (two cases in February, one in April) and the other one applied at the end of 2016 (December). Among the patients applied in 2017, two of them applied in February and the other one in April. Oropharyngeal form was detected in two patients, glandular form in one and oculoglandular form in one. All of the tularemia cases came from the same region (Cide district). History of three patients included the presence of alive or dead mouse, rabbit or rodent in the environment of home.

Conclusion: Tularemia should be considered in the differential diagnosis of patients with cervical lymphadenopathy who came from risky places especially in winter season. In endemic areas, knowledge of annual and monthly distribution of tularemia cases may be useful in providing early diagnosis to risk groups.
\end{abstract}

Keywords: Tularemia; cervical lymphadenopathy; Francisella tularensis; epidemiology.

\section{Kastamonu'da 2014-2017 yıllarında Tularemi Şüpheli Olguların Başvuru Esnasındaki Klinik ve Epidemiyolojik Özelliklerinin İncelenmesi}

ÖZ

Amaç: Tularemi, Francisella tularensis'in neden olduğu bir zoonozdur. Yerel salgınlar ya da sporadik olgular şeklinde görülmektedir. Bu çalışmada, tularemi şüpheli olguların başvuru esnasındaki klinik ve epidemiyolojik özelliklerinin incelenmesi amaçlanmıştır.

Gereç ve Yöntemler: 2014-2017 yıllarında tularemi şüpheli 36 olgu başvuru esnasındaki klinik ve epidemiyolojik özellikler açısından retrospektif olarak değerlendirilmiştir. Mikroaglütinasyon testi ile antikor seviyesi 1/160 titre ve üzerinde pozitif saptanan hastalarda tularemi tanısı konulmuştur.

Bulgular: Tularemi şüpheli 36 olgudan 4 tanesine (\%11) tularemi tanısı konuldu. Tularemi tanısı konulan toplam dört olgunun üçü 2017 yılında (iki olgu Şubat, bir olgu Nisan) diğer biri ise 2016 yılının sonunda (Aralık ayı) başvurmuştu. 2017'de başvuran hastaların ikisi Şubat ayında, bir tanesi ise Nisan ayında başvurmuştu. İki olguda orofarengeal form, bir olguda oküloglandüler form, bir olguda ise glandüler form saptandı. Olguların tamamı aynı bölgeden (Cide ilçesi) gelmişti. Üç olgunun öyküsünde ev çevresinde ölü veya canlı fare, tavşan veya kemirici varlığı mevcuttu.

Sonuç: Özellikle kış mevsiminde epidemiyolojik olarak riskli bölgeden gelen servikal lenfadenopatili olgularda ayırıcı tanıda tularemi düşünülmelidir. Endemik bölgelerde, tularemi olgularının yıllık ve mevsimsel dağı̆lım özelliklerinin bilinmesi risk gruplarında erken tanı sağlanmasında faydalı olabilir.

Anahtar Kelimeler: Tularemi; servikal lenfadenopati; Francisella tularensis; epidemiyoloji.

1 Abant Izzet Baysal University, Faculty of Medicine, Department of Infectious Diseases and Clinical Microbiology, Bolu, Turkey

2 Kastamonu State Hospital, Department of Otorhinolaryngology, Kastamonu, Turkey

Sorumlu Yazar / Corresponding Author: Hasan Tahsin GÖZDAŞ, e-mail: dr.htgozdas@yahoo.com.tr

Geliş Tarihi / Received: 27.02.2019, Kabul Tarihi / Accepted: 28.03.2019 


\section{INTRODUCTION}

Tularemia is a zoonosis caused by Francisella tularensis which is more commonly seen in the northern hemisphere (1-5). F. tularensis has the ability to reproduce intracellularly. It is quite resistant to humid environment and cold, but sensitive to chlorinated water and heat. The bacteria may infect arthropods, animals and humans. Rodents such as rabbit, mice and squirrel may act as reservoir in human infection. There are four subtypes as to be F. tularensis subsp. tularensis (type A), subsp. holarctica (type B), subsp. mediasiatica and subsp. novicida. Type A is more commonly transmitted through tick bite and rodent contact, whereas type B is more commonly transmitted through contaminated water and foods $(6,7)$. The first outbreak in Turkey was seen in Lüleburgaz in 1936. Thereafter, contaminated water associated outbreaks were reported from many cities (223). Tularemia is among the $C$ group mandatory to report diseases in the Ministry of Health communicable diseases notification system in our country since 2004 year (1).

Tularemia may be confused with many diseases and especially sporadic cases may be missed. So, tularemia cases may receive misdiagnosis and mistreatments, delay in the diagnosis and treatment may be seen $(3,4,8,11,15)$. In this study, it was aimed to evaluate clinical and epidemiological characteristics of tularemia suspected cases during admission followed-up at a secondary care hospital in Kastamonu between 2014-2017 years.

\section{MATERIAL AND METHODS}

This study was approved by the local ethics committee. Medical records of tularemia suspected cases followed-up in our hospital between 2014-2017 years were evaluated retrospectively in terms of clinical and epidemiological characteristics during admission. Diagnosis of tularemia was made according to the criteria of "Ministry of Health communicable diseases notification system, Standard Diagnosis, Surveillance and Laboratory Guideline” (1). Serum samples of clinically compatible patients were sent to National Tularemia Reference Laboratory, Public Health Institution of Turkey. Tularemia was diagnosed when the tularemia microagglutination test (MAT) was positive at 1/160 titer and above. If the antibody titer was positive below $1 / 160$ titer but clinical suspicion continued, microagglutination test was repeated two weeks later. If the repeat microagglutination test was positive at 1/160 titer and above, then these cases were also considered as tularemia cases. Diagnosis of tularemia was excluded in cases who did not meet these criteria. Cases with a previous history of tularemia were also excluded. Clinical and epidemiological characteristics of the whole cases and especially certain tularemia cases during admission were evaluated. Later properties of the cases related to follow-up such as complication, prognosis and treatment response were not investigated.

\section{Statistical Analysis}

SPSS 15.0 packet programme was used for data analysis. Descriptive statistics were shown with median, minimum and maximum value, numbers and percentages.

\section{RESULTS}

In total, 36 cases suspected of having tularemia were followed-up in our hospital between 2014-2017 years. The number of males and females were both 18 and the median age was 27.5 years (ranged from 1 to 81 ). Tularemia microagglutination test was positive at $1 / 160$ titer and above in four of the cases and these cases were diagnosed with tularemia. No case was found with antibody titer below 1/160 at first serum and a significant increase in repeat test. Three of the tularemia cases were male, one was female and the median age was 31 years (16 to 81). One of them was diagnosed at the end of 2016 year and three were diagnosed in 2017 year. The most common form was oropharyngeal form $(n=2)$. Glandular form $(n=1)$ and oculoglandular form $(n=1)$ were the other forms. Typhoidal and pneumonic form were not detected. Eleven cases were admitted either in 2014 or in 2015 (twenty-two in total), five cases in 2016 and nine cases in 2017. When looking at the months that the complaints of the tularemia cases were started; it was seen that complaints of the case in 2016 started in December, two of the three cases in 2017 in February and the other one in April.

When reviewing the distribution of tularemia cases according to districts, all of the cases came from Cide district. Other cases that were not diagnosed with tularemia mostly admitted from Kastamonu centre $(n=14)$, six cases from Cide, five from Taşköprü, three from İhsangazi, two from Devrekani and one from Doğanyurt. One case admitted from Karg1 district of Çorum was also tularemia-like case. Complaints of the definitive tularemia cases from Cide district started almost in the same time period (December 2016, February 2017 and April 2017). Two cases admitted in February 2017 and were farming-animal husbandry. An epidemiological connection was thought to be present between these two cases.

The median day between the start of complaints and hospital admission was 7 days (1-365). Swelling/pain in the neck was detected in $100 \%(n=36)$ of the patients, malaise in $72 \%(n=26)$ of the patients. Malaise, sore throat and swelling/pain in the neck were present in all cases of definitive tularemia, fever was present in $75 \%$ $(n=3)$, myalgia/arthralgia and redness/swelling in the eye were present in $50 \%(n=2)$.

The most common physical examination finding during admission was cervical lymphadenopathy which was found in all patients. High fever was detected in 17 cases, tonsillopharyngitis in 15 cases, skin lesion in four cases, oral mucosa lesion in two cases and conjunctivitis in one patient.

In physical examination of the four cases with definitive diagnosis, cervical lymphadenopathy was detected in all, fever in three, tonsillopharyngitis in two and conjunctivitis in one. With respect to living in risky places, $64 \%$ of the whole cases $(n=23)$ and all cases with definitive diagnosis $(n=4)$ were living in rural area. With respect to occupational risk $50 \%$ of the whole cases $(n=18)$ and three fourths of the cases with definitive diagnosis were doing hunting, farming, animal husbandry, butchery and agriculture which are risky occupations for tularemia. 
While the rate of using city water was $78 \%(n=28)$ in the whole cases, this rate was $75 \%(n=3)$ in cases with definitive diagnosis. Cases who do not use city water were using water from the sources such as street/village fountain, lake and borehole. When reviewing the epidemiological characteristics of the patients, it was seen that the rate of similar person in the near environment of the patient within one month before the start of complaints was $8.3 \%(n=3)$ in the whole group, however this rate was $33.3 \%(n=1)$ in the tularemia group.

\section{DISCUSSION}

Among 36 suspected cases, four cases were diagnosed with tularemia and the most common form was oropharyngeal form. While there was no case diagnosed with tularemia in 2014 and 2015, tularemia cases were seen in the winter season of 2016 and 2017 and all of the cases came from Cide district. In our study, living in rural area and the rate of similar person in the patient's near environment was found higher in cases diagnosed with tularemia.

In a study conducted in our hospital in 2012-2013, it was indicated that out of 50 tularemia suspected cases, 17 (34\%) received tularemia diagnosis and similar to the present study most of the cases (59\%) came from Cide district (24). When 2012-2013 and 2014-2017 periods were compared, the number of either tularemia suspected cases or definitive tularemia cases decreased in Kastamonu city. The decrease in the number of cases is significant, because it shows that the epidemiology of tularemia may change within years.

The first tularemia outbreak in Turkey was detected in Lüleburgaz in 1936. Thereafter, tularemia was reported from many cities. It usually appears as local outbreaks, however sporadic cases were also reported (2-21,24,27). While almost 1000 cases were reported between 1989 and 2004, 431 cases were reported in 2005. In the next three years, a serious decrease was seen in the number of cases, only 71 cases were reported in 2008. After 2009, the number of cases increased again. The number of reported cases from our country in 2009, 2010, 2011 and 2012 were 428, 1531, 2151 and 607, respectively (9). In Turkey, most outbreaks were seen in the Marmara and western Black Sea region until 2004. After 2005, notifications were also conducted from Middle Anatolia (2,3,5-18). In our country, human tularemia cases are generally followed as small clusters, however local outbreaks are seen in every two or three years in endemic areas (2,6-18). At the time of outbreaks, almost half of the cases composed of intrafamily cases $(2,8,18,19)$. In our study, since two cases detected in 2017 admitted at the same time period and came from the same place, epidemiological connection was thought to be present between these two cases. Supporting this idea, the frequency of similar patient in the environment was found higher (33.3\%) in cases with definitive tularemia. In previous studies from our country, it was reported that tularemia is more frequently seen in adult females (above 30 years) $(2,12,19,23)$. In our study, the median age of the cases suspected of having tularemia was 27.5, however the median age of the cases with definitive diagnosis was 31 . Three of the four cases with a definitive diagnosis were male. In our study, high frequency of male gender in tularemia cases may be related to the fact that males more often work in rural areas and conduct risky processes. Most tularemia cases in our country are the persons dealing with farming. Tularemia is usually seen in farmers, hunters, forest workers and relatives of these persons $(6,8,11,12,14)$. In our study, all of the cases diagnosed with definitive tularemia were living in rural area.

Although tularemia may be seen in every season in our country, the number of cases generally show increase in the late autumn and winter months, the frequency is low in spring and summer months $(1,5,7,9)$. Similarly, definitive tularemia cases admitted in late autumn and winter season in our study. In 2004-2005 outbreaks affecting Bartın, Zonguldak and Kastamonu, cases were seen in December-April months mostly in February (8). Definitive cases were seen in December, February and April in our study, too. So, clinicians should consider tularemia in the differential diagnosis of patients with cervical lymphadenopathy who admitted in late autumn and winter.

Clinical presentation of the disease may vary according to the immunologic status of the host, transmission way of the disease, amount and subtype of bacteria. In our country, asymptomatic/subclinical cases were reported to be $4-19 \%$ in the outbreaks, tularemia seroprevalence was reported to be $0.3-20.9 \%(9,20,21,25,26)$. In our country, oropharyngeal form is the most reported form and the majority of outbreaks was found to be related with contaminated water and food. Oculoglandular form is the second most common form, ulceroglandular and glandular form are seen very rarely. Pneumonic and typhoidal form were reported extremely rare $(1,5,7,9,27)$. It is well-known that complaints such as fever, sore throat and headache which are seen in the early period of tularemia disappear two weeks later, but enlargement in cervical lymph nodes continues (10). The median time that the definitive tularemia cases admitted to our hospital was 15 days. While oropharyngeal form was the most detected form in our study, the rate of city water use in definitive tularemia cases is $50 \%$. The low rate of city water use supports transmission through contaminated water $(9,10)$.

Tularemia is generally diagnosed by serological tests in the presence of appropriate clinical findings because of high virulence and low culture sensitivity of F. tularensis. Antibodies against tularemia can be detected in serum two weeks after the symptoms started. MAT is still the most widely used serological method. For the diagnosis of acute infection, antibody levels at 1/160 titer and above are accepted as significant. In cases with negative culture and serology, polymerase chain reaction is the other method that can be used $(1,5-7)$. In our study, $F$. tularensis could not be cultured, however MAT was repeated in the presence of ongoing clinical suspicion.

The limitations of our study are retrospective, single centre and small sample size. All tularemia suspected cases admitted to our hospital between 2014-2017 years were enrolled to this study, but they could be evaluated only in terms of characteristics during admission. It will be useful if tularemia suspected cases are evaluated with further studies including more cases. The strengths of our study are evaluation of cases in Kastamonu individually 
and being instructive to the cases that tularemia was thought of in the differential diagnosis.

In conclusion, tularemia should always be thought in the differential diagnosis of patients from endemic regions who admitted with cervical lymphadenopathy in late autumn and winter, especially who lived in rural area, if there is similar patient in the close area and who did not use city water. Determination of the seasonal and annual distribution of tularemia cases in endemic regions by the clinicians will be useful for the early diagnosis of the disease.

\section{REFERENCES}

1. Ulusal Mikrobiyoloji Standartları: Bulaşıcı Hastalıklar Laboratuvar Tanı Rehberi. Ankara: T.C. Sağlık Bakanlığı, Türkiye Halk Sağlığı Kurumu, Mikrobiyoloji Referans Laboratuvarları Daire Başkanlığı; 2014.

2. Bozkurt $\dot{\mathrm{I}}$, Kiliç S. Tularemia is spreading from north to south side of Turkey: A small outbreak in Kahramanmaras, Turkey. Mikrobiyol Bul. 2014; 48(3): 413-9.

3. Tatman Otkun M, Akçalı A, Karadenizli A, Ozbey N, Gazel D, Sener A, et al. Epidemiological evaluation of a rapidly-prevented tularemia outbreak in Canakkale province, Turkey. Mikrobiyol Bul. 2011; 45(1): 48-57.

4. Karakeçili F, Akın H, Torun MT, Akalın EH, Helvacı S. Evaluation of case series of delayed tularaemia. Int J Res Med Sci. 2017; 3(12): 3893-6.

5. Tularemi Hastalığının Kontrolü için Saha Rehberi. Ankara: T.C. Sağlık Bakanlığı Temel Sağlık Hizmetleri Genel Müdürlüğü Zoonotik Hastalıklar Daire Başkanlığı; 2011.

6. Gürcan S. Francisella tularensis and tularemia in Turkey. Mikrobiyol Bul. 2007; 41(4): 621-36.

7. Kılıç S. A general overview of Francisella tularensis and the epidemiology of tularemia in Turkey. Flora. 2010; 15(2): 37-58.

8. Celebi G, Baruönü F, Ayoğlu F, Cinar F, Karadenizli A, Uğur MB, et al. Tularemia, a reemerging disease in northwest Turkey: Epidemiological investigation and evaluation of treatment responses. Jpn J Infect Dis. 2006; 59(4): 229-34.

9. Gürcan S. Epidemiology of tularemia. Balkan Med J. 2014; 31(1): 3-10.

10. Sahin M, Atabay HI, Bicakci Z, Unver A, Otlu S. Outbreaks of tularemia in Turkey. Kobe J Med Sci. 2007; 53(1-2): 37-42.

11. Ozdemir D, Sencan I, Annakkaya AN, Karadenizli A, Guclu E, Sert E, et al. Comparison of the 2000 and 2005 outbreaks of tularemia in the Duzce region of Turkey. Jpn J Infect Dis. 2007; 60(1): 51-2.

12. Dikici N, Ural O, Sümer S, Oztürk K, Albayrak Yiğit O, Katlanır E, et al. Tularemia in Konya region, Turkey. Mikrobiyol Bul. 2012; 46(2): 225-35.

13. Barut S, Cetin I. A tularemia outbreak in an extended family in Tokat Province, Turkey: Observing the attack rate of tularemia. Int J Infect Dis. 2009; 13(6): 745-8.

14. Sencan I, Sahin I, Kaya D, Oksuz S, Ozdemir D, Karabay O. An outbreak of oropharyngeal tularemia with cervical adenopathy predominantly in the left side. Yonsei Med J. 2009; 50(1): 50-4.

15. Akıncı E, Ulgen F, Kılıç S, Yılmaz S, Yıldız S, Özdemir B, et al. Evaluation of tularemia cases originated from Central Anatolia, Turkey. Mikrobiyol Bul. 2011; 45(4): 762-4.

16. Engin A, Altuntaş EE, Cankorkmaz L, Kaya A, Elaldı N, Şimşek H ve ark. Sivas ilinde saptanan ilk tularemi salgını. Klimik Derg. 2011; 24(1): 17-23.

17. Erdem H, Ozturk-Engin D, Yesilyurt M, Karabay O, Elaldi N, Celebi G, et al. Evaluation of tularaemia courses: A multicentre study from Turkey. Clin Microbiol Infect. 2014; 20(12): 1042-51.

18. Balci E, Borlu A, Kilic AU, Demiraslan H, Oksuzkaya A, Doganay M. Tularemia outbreaks in Kayseri, Turkey: An evaluation of the effect of climate change and climate variability on tularemia outbreaks. J Infect Public Health. 2014; 7(2): 125-32.

19. Mengeloglu Z, Duran A, Hakyemez IN, Ocak T, Kücükbayrak A, Karadag $M$, et al. Evaluation of patients with Tularemia in Bolu province in northwestern Anatolia, Turkey. J Infect Dev Ctries. 2014; 8(3): 315-9.

20. Gedikoğlu S, Göral G, Helvacı S. Bursa'daki tularemi epidemisinin özellikleri. Turkish J Infect. 1990; 4(1): 9-15.

21. Gurcan S, Otkun MT, Otkun M, Arikan OK, Ozer B. An outbreak of tularemia in Western Black Sea region of Turkey. Yonsei Med J. 2004; 45(1): 17-22.

22. Eren Gok S, Kocagul Celikbas A, Baykam N, Atay Buyukdemirci A, Eroglu MN, Evren Kemer O, et al. Evaluation of tularemia cases focusing on the oculoglandular form. J Infect Dev Ctries. 2014; 8(10): 1277-84.

23. Kaya A, Deveci K, Uysal IO, Güven AS, Demir M, Uysal EB, et al. Tularemia in children: Evaluation of clinical, laboratory and therapeutic features of 27 tularemia cases. Turk J Pediatr. 2012; 54(2): 105-12.

24. Hekimoğlu CH, Demirci NA, Güleç GU. Investigation of clinical and epidemiological characteristics of cases with a diagnosis of tularemia during admission in Kastamonu. Flora. 2015; 20(3): 150-6.

25. Dedeoğlu Kılınç G, Gürcan S, Eskiocak M, Kılıç H, Kunduracilar $\mathrm{H}$. Investigation of tularemia seroprevalence in the rural area of Thrace region in Turkey. Mikrobiyol Bul. 2007; 41(3): 411-8.

26. Yazg1 H, Uyanık MH, Ertek M, Kılıç S, Kireçci E, Özden K, et al. Tularemia seroprevalence in the risky population living in both rural and urban areas of Erzurum. Mikrobiyol Bul. 2011; 45(1): 67-74.

27. Şencan İ, Kaya D, Öksüz Ş. Salmonelloz ön tanısı ile izlenen bir tifoidal tularemi olgusu. Klimik Derg. 2000; 13(3): 113-6. 